\title{
THE
}

\section{Complex transboundary movements of marine megafauna in the Western Indian Ocean}

\author{
A.N. Barkley \\ M Gollock \\ M Samoilys \\ F Llewellyn \\ M Shivji
}

See next page for additional authors

Follow this and additional works at: https://digitalcommons.uri.edu/bio_facpubs

The University of Rhode Island Faculty have made this article openly available.

Please let us know how Open Access to this research benefits you.

This is a pre-publication author manuscript of the final, published article.

Terms of Use

This article is made available under the terms and conditions applicable towards Open Access Policy Articles, as set forth in our Terms of Use.

\section{Citation/Publisher Attribution}

Barkley, A.N., Gollock, M., Samoilys, M., Llewellyn, F., Shivji, M., Wetherbee, B. and Hussey, N.E. (2019), Complex transboundary movements of marine megafauna in the Western Indian Ocean. Anim Conserv, 22: 420-431. https://doi.org/10.1111/acv.12493 


\section{Authors}

A.N. Barkley, M Gollock, M Samoilys, F Llewellyn, M Shivji, Bradley M. Wetherbee, and N.E. Hussey

This article is available at DigitalCommons@URI: https://digitalcommons.uri.edu/bio_facpubs/260 
3 Amanda N. Barkley ${ }^{1}$, Matthew Gollock ${ }^{2}$, Melita Samoilys ${ }^{3}$, Fiona Llewellyn ${ }^{2}$, Mahmood Shivji ${ }^{4}$,

4 Bradley Wetherbee ${ }^{4,5}$, Nigel E. Hussey ${ }^{1 *}$

$6{ }^{1}$ University of Windsor, Biological Sciences, Windsor, Ontario, Canada. 401 Sunset Ave. N9B

$7 \quad 3 \mathrm{P} 4$

$8 \quad{ }^{2}$ Zoological Society of London, Regent's Park, London, England

$9{ }^{3}$ Coastal Oceans Research and Development - Indian Ocean, Mombasa, Kenya

$10{ }^{4}$ Guy Harvey Research Institute and Department of Biological Sciences, Nova Southeastern

11 University, Fort Lauderdale, Florida, USA

$12{ }^{5}$ University of Rhode Island, Biological Sciences, College of Environment and Life Sciences,

13 Kingston, Rhode Island, USA

14

15 *Corresponding author: nehussey@uwindsor.ca

16

17 Running title: Transboundary movements in the WIO 


\section{Abstract}

2 Transboundary marine species have an increased risk of overexploitation as management regimes

3 and enforcement can vary among states. The complex geopolitical layout of exclusive economic

4 zones (EEZs) in the Western Indian Ocean (WIO) introduces the potential for migratory species to

5 cross multiple boundaries, consequently a lack of scientific data could complicate regional

6 management. In the current study we highlight both the relative lack of spatial data available in the

7 WIO, and the prevalence of transboundary movements in those species that have been studied. Five

8 tiger sharks (Galeocerdo cuvier) were tracked with near real time positioning (SPOT) satellite tags

9 to determine individual shark movements relative to EEZs within the WIO. Concurrently, a

10 literature search was performed to identify all satellite telemetry studies conducted to date in the

11 WIO for marine megafunal species, and the results compared to global satellite telemetry effort.

12 Finally, the satellite tracks of all marine species monitored in the WIO were extracted and digitized

13 to examine the scale of transboundary movements that occur in the region. Tiger sharks exhibited

14 both coastal and oceanic movements, with one individual crossing a total of eight EEZs. Satellite

15 telemetry effort in the WIO has not matched the global increase, with only $4.9 \%$ of global studies

16 occurring in the region. Species in the WIO remained within the EEZ in which they were tagged in

17 only three studies, while all other species demonstrated some level of transboundary movement.

18 This study demonstrates the lack of spatial data available for informed regional management in an

19 area where transboundary movements by marine species are highly prevalent. Without more

20 dedicated funding and research, the rich biodiversity of the WIO is at risk of overexploitation from

21 the diverse threats present within the various political regions.

23 Keywords: Western Indian Ocean, spatial management, tiger sharks, exclusive economic zones,

24 satellite tags, telemetry, tracking, transboundary, migration 


\section{Introduction}

The establishment of marine boundaries is necessary for resource allocation among states

3 and stakeholders and are used frequently for conservation efforts (Song et al., 2017). One of the

4 most prominent examples of marine boundaries are exclusive economic zones (EEZs) in which a

5 state is given sovereign rights for the exploitation and conservation of the natural resources

6 contained within. However, geopolitical boundaries such as EEZs, with varying policies and

7 governance, rarely reflect the natural boundaries of the biological resources they contain, leading

8 to an increased risk of over-exploitation when international agreements or basic knowledge on

9 species distributions are lacking (Folke, 2007; McWhinnie, 2009). In particular, the development

10 of effective co-management for highly migratory fish stocks and bycatch species among states can

11 be severely hindered by the often complex life histories of these animals that impede research,

12 resulting in a lack of scientific data to support management (Lascelles et al., 2014).

13 Over the past two decades, the ability to monitor and manage mobile marine species has

14 radically improved with the advent and technological advances of telemetry (Cooke et al., 2004;

15 Hussey et al., 2015; Hays et al., 2016). Specifically, satellite tracking has enabled the identification

16 of hotspot and aggregation sites (Block et al., 2011), elucidated spatial and temporal limits of

17 migration corridors (Morreale et al., 1996) and identified philopatric behaviour of elusive

18 megafauna (Bonfil et al., 2005; Jorgensen et al., 2009; Werry et al., 2014). With recognition of

19 inter-annual variation in environmental conditions that regulate animal movements, telemetry data

20 are also now guiding flexible and adaptive fisheries management approaches and investigating how

21 ongoing climate change will shape species distributions (McMahon \& Hays, 2006; Maxwell et al.,

22 2015; Crossin et al., 2017). Moreover, these satellite tracking data can be used to direct the

23 designation and test the effectiveness of boundaries established for conservation such as marine

24 protected areas (MPAs) as well as determine the extent of movement within transboundary fish

25 stocks with regards to EEZs and international waters (Ballard et al., 2012; Howey-Jordan et al.,

26 2013; White et al., 2017). To date, however, it would appear there is a bias in the focus of global 
1 satellite telemetry efforts towards more developed countries (Hussey et al., 2015), limiting their

2 potential for management in less developed areas that urgently require monitoring of both

3 commercially important and imperilled species.

4 The Western Indian Ocean (WIO), a distinct biogeographic province (Spalding et al., 2007;

5 Obura, Church \& Gabrié, 2012), and a significant portion of FAO area 51 (FAO, 2017), represents

6 a region that is telemetry data poor. While there are mounting concerns over the status of WIO

7 fisheries regarding both the sustainability of targeted fisheries as well as bycatch of large predators

8 including elasmobranchs (Robinson \& Sauer, 2013; Sumaila et al., 2014; Samoilys et al., 2017;

9 WCS in press), there is a significant lack of data to delimit species distributions and core habitats

10 to aid in the development of effective MPAs and co-management efforts among states. The

11 importance of the WIO as a global biodiversity hotspot (Obura et al., 2012; Worm \& Branch, 2012),

12 combined with the complex geopolitical layout of its numerous EEZs suggests a need for increased

13 analysis into the distribution of the diverse mobile fauna in the region.

14 Tiger sharks (Galeocerdo cuvier) are widely distributed across the tropics and display complex

15 migratory behaviours such as partial migration whereby some individuals remain resident in coastal

16 waters while others undertake long-distance migrations (Papastamatiou et al., 2013; Holmes et al.,

17 2014). In the nearshore environment of Reunion Island in the WIO, acoustically-tagged tiger sharks

18 display sex-dependent seasonal fluctuations in abundance, however the extent of their offshore

19 movements remains unknown (Blaison et al., 2015). These large, apex predators likely play an

20 important top down role in marine ecosystems (Navia, Cortés \& Mejía-Falla, 2010), yet the

21 presence of threats such as commercial shark fishing and localized shark control programs have the

22 potential to impact tiger shark populations (Dudley \& Simpfendorfer 2006; Blaison et al., 2015;

23 Samoilys et al., 2015), making them an ideal focal species to highlight the complexity of

24 management in the WIO.

25 In the current study, we use novel tracks of tiger sharks to demonstrate issues facing the 26 management of migratory megafauna in the WIO. The objectives of the study were to (i) summarize 
1 satellite telemetry monitoring undertaken to date in the WIO and compare to the scale of global

2 monitoring, (ii) use satellite tracks of tiger sharks to show complex regional transboundary

3 movements in the WIO and (iii) synthesize all satellite telemetry studies in the WIO to date, to

4 determine if large-scale movements of megafauna commonly cross the region's numerous

5 geopolitical boundaries. We sought to assess the relative needs and issues around managing mobile

6 species in the WIO and highlight the requirement for investment in research for the WIO's

7 developing countries to improve regional scale management.

9 Materials and Methods

\section{Literature review}

11 All global satellite telemetry studies undertaken up to December 2013 were accessed from Hussey

12 et al. (2015) and updated for the WIO up to December 2016. In brief, telemetry studies were

13 identified using an ISI Web of Science search with the search term 'satellite', 'PSAT' and 'SPOT'

14 followed by each of the words, 'telemetry', 'tracking' and 'tag'. In addition, any studies cited in

15 the identified publications, but not highlighted in the original search were included. The cumulative

16 number of global satellite telemetry studies over time was then calculated and compared with those

17 undertaken specifically in the WIO region. The countries of the WIO are defined as the ten member

18 states of the Nairobi Convention (2010) and span from Somalia to South Africa on the mainland

19 eastern African coast, and extend to the island states of Seychelles, Comoros, Madagascar,

20 Mauritius and include the French Southern Territories.

\section{Satellite telemetry tracking of tiger sharks}

\section{Study location, capture and tag attachment}

24 Tiger sharks were caught on the Watamu Bank ( $\left.3^{\circ} 24.00^{\prime} \mathrm{S}, 40^{\circ} 08.00^{\prime} \mathrm{E}\right)$, northern Kenya. The bank

25 is approximately $1.6 \mathrm{~km}$ long with depths between 50 and $100 \mathrm{~m}$ that drop off into deeper

26 surrounding waters. Sharks were caught using standard recreational fishing gear (rod and reel) with 
1 yellowfin tuna as bait. Once hooked, sharks were guided in next to the boat and a wire strap passed

2 over the head and body to secure the caudal fin. A lifting strap was placed around the mid-section,

3 posterior to the pectoral fins and anterior to the dorsal fin to secure the mid-section of the animal.

4 The rear platform of the boat was partially submerged allowing irrigation of the gills with seawater

5 as the boat drifted. Length measurements, fork and total length (FL and TL; cm) were recorded as

6 the distance from the tip of the snout to the centre of the caudal keel and as a direct line to the top

7 of the caudal fin, respectively. Sex was recorded based on the presence (male) or absence (female)

8 of claspers.

9 To track the horizontal movements of tiger sharks, SPOT5 tags (models 257A and 258A with

10 battery life of 980 and 220 days, respectively; Wildlife computers Ltd, Redmond, Seattle) were

11 attached to the dorsal fin. To attach the tags, a template was held against the fin and four holes

12 drilled using a hand held electric drill. The SPOT5 tag was then attached by inserting a rod through

13 the fin and securing the tag with washers to the rods by inserting two screws into either end. Once

14 the tag was secured, the straps were removed, the shark held by the caudal fin, and released once

15 strokes were powerful enough to propel the animal forward. Its post release behaviour was then

16 monitored from the surface and with a GoPro camera held underwater by the side of the boat. All

17 animal handling was approved under the animal care protocol for the Zoological Society of London.

\section{Data processing and analyses}

20 For all SPOT tag data, ARGOS location estimates were first screened to remove invalid positions

21 (primarily location class $\mathrm{Z}$ or 0 ). The geolocations were then filtered using a Bayesian state-space

22 model through the package 'bsam' in $\mathrm{R}$ ( $\mathrm{R}$ core team 2018) and interpolated into regular time

23 intervals of 24 hours. The $24 \mathrm{~h}$ position estimates were plotted for each individual shark using GIS

24 software (ArcGIS 10.2.2, esri 2014) and overlaid on regional exclusive economic zones (EEZs) to

25 determine the relative number of days spent within each EEZ and international waters. EEZ

26 boundaries were sourced from the Flanders Marine Institute (2016), cognisant that some of these 
1 are disputed (Okonkwo, 2017). The relative number of days each shark spent in different EEZs was

2 calculated as the number of daily positions located within each EEZ divided by the total number of

3 tracking days for that individual. The total distance travelled by each shark was also calculated in

4 ArcGIS as the cumulative distance between each daily position.

6 Synthesis of satellite telemetry studies in the WIO

7 To examine spatial movement patterns of all marine species equipped with satellite tags in the WIO

8 relative to geopolitical regions and associated EEZs, animal tracks from published papers were

9 digitized in ArcGIS. Map images extracted from published papers were georeferenced by matching

10 coastlines within the image to a shapefile with known geographic coordinates. Animal tracks were

11 then traced with points or lines where appropriate. Digitization resulted in a certain level of

12 distortion of the track data; however, tracks were accurate enough for the broad-scale analysis of

13 presence within an EEZ. In many cases, separating the tracks of individual animals of the same

14 species per publication was not possible; therefore, data were combined at the species level. Studies

15 that re-used telemetry data, or which contained both novel and shared data were combined into one

16 reference track, while studies examining multiple species were separated by species. Finally,

17 studies that manipulated the movements of animals (for example, through translocation to a

18 different area prior to release) as well as reviews were omitted from the analysis.

\section{Results}

\section{Literature review}

22 Of the total 597 global satellite telemetry studies (Hussey et al., 2015), only 28 (4.7\%) occurred in

23 the WIO (Fig. 1), with the majority of these (17; 60.7\% of WIO total) undertaken off South Africa

24 (a list of data sources can be found in Appendix 1). When considering species tagged, 15 (53.6\%)

25 monitored the movements of turtles (green [Chelonia mydas], leatherback [Dermochelys coriacea]

26 and loggerhead [Caretta caretta]), however these studies often re-used the same telemetry data for 
1 different applications, while others focused on turtle behaviour following displacement (Table 1).

2 Additional species where multiple studies were conducted included whale sharks (Rhincodon

3 typus: $4 ; 14.3 \%$ ) tagged off Seychelles, Mozambique and South Africa as well as southern right

4 whales (Eubalaena australis: 2; 7.1\%; Fig. 2) tagged at three independent sites off South Africa.

5 Also of note, sample sizes within papers were typically low, with 13 instances where five or less

6 animals of the same species were tagged (Table 1). Lastly, the study by Roquet et al., (2014) used

7 satellite-tracked elephant seals (Mirounga leonine) to obtain hydrographic profiles off the coast of

8 South Africa but was not included in the following analysis as movement data could not be

9 extracted.

10 Tiger shark satellite telemetry

11 Five tiger sharks ranging in total length from $280-380 \mathrm{~cm}$ TL were equipped with SPOT5

12 satellite tags off northern Kenya. Of the five sharks, four successfully transmitted geolocation data

13 to ARGOS. The average time between transmissions was $0.42 \pm 1.4$ days, suggesting that daily

14 positions from the SSM were appropriate (Block et al., 2011). There was only one instance where

15 the time between transmissions was >20 days (near the end of TS04's transmissions), however

16 given that the locations before and after this time gap were both within the Tanzania EEZ, it was

17 not split. Track periods for three tiger sharks were less than three months while one individual was

18 monitored for five months.

19 Sharks TS01 and TS02 spent their entire track time (44 and 35 days respectively) within the

20 Kenyan EEZ (Figs. 3 \& 4), while TS04 moved along the coast transiting back and forth between

21 Kenya (number of days [\% of total track days]: 41 [17\%]) and Tanzania (194 [83\%], Figs. 3 \& 4).

22 Shark TS03 moved offshore, spending time in seven different EEZs: Kenya (1 [2\%]; where the

23 shark was tagged), Comoros (12 [18\%]), Seychelles (5 [8\%]), Iles Eparses (14 [21\%]) and Mayotte

24 (10 [15\%]; both French southern territories), Mozambique (3 [5\%]) and Madagascar (17 [26\%]),

25 as well as international water (4 [6\%], Figs. $3 \& 4)$. 
Synthesized satellite telemetry studies for the WIO resulted in data from 20 references (defined

3 as single tracks; see methods) for 10 species (Figs. $2 \& 5$ ). Of these 20 tracks, there were only three

4 instances (15\%) where the animals stayed within the EEZ where they were tagged and released,

5 two of which were turtles (green and loggerhead; Fig. 5) and the third the sand tiger shark

6 (Carcharias taurus; Fig. 5). All other species tracks showed movements away from their tagging

7 EEZ into those of neighbouring countries or international waters (Figs. $2 \& 5$ ). The number of

8 transboundary movements was highest for marine mammals (number of EEZs \pm SD; $6 \pm 2$ ) and

9 similar for elasmobranchs and reptiles ( $4 \pm 3$ and $3 \pm 4$, respectively).

\section{Discussion}

12 The WIO is characterized by a complex geopolitical layout of states with multiple marine

13 boundaries that intersect an ocean rich in species biodiversity. This complexity presents a challenge

14 for management, as political boundaries do not reflect the distributions of highly mobile marine

15 species. Given the limited number of studies undertaken to date, satellite telemetry effort in the

16 WIO does not reflect the scientific knowledge required on species movements, highlighting an

17 urgent call for invested effort in this data-poor region. Synthesized tracking data as well as novel

18 satellite tracks of tiger sharks off Kenya, highlight how megafauna in the WIO cross multiple EEZs,

19 making conservation efforts difficult in the face of varying management and enforcement regimes.

20 Since the advent of satellite telemetry, there has been an exponential increase in its

21 application to understand aquatic species globally (Hussey et al., 2015). Studies occur across

22 diverse water bodies, including remote regions such as the poles (Dalla Rosa et al., 2008; Fisk,

23 Lydersen \& Kovacs, 2012) and the deep sea (Peklova et al., 2012), but areas of the developing

24 world are lacking. Considering only $2 \%$ of global telemetry studies have occurred in the WIO, with

25 its rich species diversity and endemism (Allen, 2008; Wafar et al., 2011; Obura et al., 2012), the

26 need for more dedicated research and funding is apparent. Marine biodiversity estimates in the 
1 southern WIO are some of the highest globally (Tittensor et al., 2010), where 161 of these species

2 have been identified as threatened (defined as species that are critically endangered, endangered or

3 vulnerable on the IUCN red list; Richmond, 2015). Of particular note, the WIO is a global hotspot

4 for oceanic taxa (Tittensor et al., 2010), highlighting the urgent need for regional information on

5 species' spatial ecology. Increasingly, studies focused on animal movements to determine stock

6 distribution have led to changes in management and improved conservation regimes (Kaunda-Arara

7 \& Rose, 2004; Espinoza et al., 2015; Hussey et al., 2017; reviewed in Crossin et al., 2017). This

8 demonstrates the benefit of investing in telemetry to improve our ability to develop meaningful,

9 practical and beneficial legislation.

10 Very little is currently known about the movements of tiger sharks in the WIO and

11 population indices are contrasting, with one study off South Africa suggesting numbers may be

12 increasing (Dudley \& Simpfendorfer 2006), while a failure to record tiger sharks on coral atolls off

13 East Africa was attributed to fishing and bycatch (Clarke, Lea \& Ormond, 2012). Without even a

14 basic understanding of tiger shark spatial ecology in the WIO, localized population estimates may

15 be ineffective in describing accurate population trends as they may target animals of only a certain

16 life stage, or they may be targeting mixed populations whereby one is healthy while the other is

17 experiencing potentially harmful declines that are masked in the survey (Cooke et al., 2016). In the

18 present study, the two sharks that were tracked for $>60$ days exhibited a divide in spatial use, with

19 one remaining along the coast and continental shelf, while the second moved into the open ocean,

20 similar to movements described in both Australia and the Hawaiian Islands (Papastamatiou et al.,

21 2013; Holmes et al., 2014). Tiger sharks recently tracked off South Africa also demonstrated a mix

22 of coastal and oceanic movements, however coastal movements were most prominent with

23 relatively restricted spatial use (Daly et al., 2018). The presence of tiger sharks in extremely shallow

24 waters along the coast of Kenya as well as over the deep waters of the high seas highlights their

25 vulnerability to multiple fishing operations. Typically, small-scale fisheries operate close to shore

26 while larger, industrial vessels of predominantly foreign fleets exploit the offshore (Branch et al., 
1 2002; Mora et al., 2009). The occurrence of tiger sharks in both regions suggests they are likely

2 targets of intense artisanal fisheries as well as both the target and bycatch of commercial fleets.

3 Although illegal fishing in the WIO may be declining (Agnew et al., 2009), overall fishing effort

4 is increasing with concerns over under-reported catches (FAO, 2016) where large elasmobranchs

5 such as the tiger shark may be targeted for the fin trade.

6 The loss of two satellite tags (TS 01 and TS 02) in the present study well before the 7 expected life-span of the instruments could be a result of multiple factors. The tag model of these 8 two differed from the others (257A vs. 258A), with a smaller housing and shorter battery life that

9 may be more prone to device failure. Indeed, other studies have reported SPOT satellite tag failures 10 on tiger sharks around or before 30 days (Heithaus et al., 2007; Meyer, Papastamatiou \& Holland, 11 2010; reasons for failure reviewed in Hays et al., 2007). However, the area around Lamu, north of 12 Watamu where the current study took place, was historically a shark fishing region (Marshall, 13 1998) and traditional practices have continued to this day, although catch rates have been in decline 14 (Samoilys et al., 2015). The presence of sharks in these shallow, coastal waters prior to tag failure 15 may suggest that the tag stopped transmitting as a result of fisheries capture. Artisanal fisheries 16 target nearly all catchable species and monitoring of elasmobranch catch is limited or near non17 existent so the true catch of these taxa in the region remain relatively unknown (Smale, 2008; Pauly, 18 2015; Robinson \& Sauer, 2013; Samoilys et al., 2017).

19 The movements of tiger sharks in the present study highlights a common trend among 20 telemetered species in the WIO: far-ranging species often cross multiple political boundaries. For 21 example, one of the tagged tiger sharks travelled $4779 \mathrm{~km}$ and crossed into eight EEZs. 22 Transboundary and highly migratory fish are at a greater risk of being overharvested because the 23 status of shared stocks is difficult to determine (Bjørndal et al., 2000; McWhinnie, 2009; White \& 24 Costello, 2014), and spatial conservation efforts (such as MPAs) are often less effective than for 25 sedentary species, especially with limited spatial data (West et al., 2009; Lascelles et al., 2014). 26 Given policies for transboundary fish are required to be far-ranging, they inevitably impact a large 
1 and diverse group of stakeholders that might be less inclined to agree with, and adapt to, changes

2 in management (Song et al., 2017). Even in instances where states are motivated to implement co-

3 management regimes, variability in stability, prosperity, and institutional capacity can affect

4 enforcement, ultimately resulting in a regional disparity in levels of protection. In the WIO there

5 exists abundant legislation and policies for the protection of marine and coastal environments that

6 scale from the local and/or state level, to regional and global inter-governmental institutions. One

7 of the most prominent regional governmental partnerships is the Nairobi Convention, signed in

81985 which has been instrumental in laying the framework for the development of institutions,

9 policies and legislation to protect the marine environment. However, the existence of these

10 institutions does not immediately translate to environmental protection, as multiple transboundary

11 issues have been identified, but have yet to be resolved due to the complex nature of addressing

12 their root causes (UNEP/Nairobi Convention Secretariat and WIOMSA, 2009; Momanyi, 2015;

13 Okonkwo, 2017). For example, social issues such as poverty and limited capacity to administer

14 compliance activities contribute to habitat destruction, pollution, and unregulated fishing which in

15 turn impact commercial and non-commercial marine species abundance (UNEP/Nairobi

16 Convention Secretariat and WIOMSA, 2009; Samoilys et al., 2015). The plethora of governmental

17 institutions can also negatively impact meaningful change when mandates are overlapping,

18 contradictory, inconsistent, and/or poorly enforced (Momanyi, 2015). There are also EEZ boundary

19 disagreements between neighbouring states, which have a direct impact on the marine environment

20 (Okonkwo, 2017). Finally, a consistent and reoccurring theme in addressing transboundary

21 resources in the WIO is the lack of scientific data to support and inform management, as regional

22 institutions cannot implement effective governance without sound evidence to direct decision-

23 making (UNEP/Nairobi Convention Secretariat and WIOMSA, 2009; Momanyi, 2015; Samoilys

24 et al., 2015).

25 Although the number of studies investigating marine megafaunal movements in the WIO

26 are limited, synthesized results demonstrate that significant regional cooperation will be needed to 
1 manage wide ranging species, while also highlighting cases where local MPAs may also be

2 effective for species protection. For example, when considering localized management, inter-

3 nesting loggerhead turtles remained close to shore, not only within the EEZ in which they were

4 tagged, but also inside coastal reserves and MPAs (Harris et al., 2015). However, juvenile

5 loggerhead turtles tagged off Reunion Island crossed 13 EEZs demonstrating this species may be

6 much more vulnerable in its early years (Dalleau et al., 2014). Similarly, post-nesting green turtles

7 tagged off St. Joseph Island in the Seychelles demonstrated relatively restricted foraging

8 migrations, with genetic evidence suggesting a discreet population that would require local

9 conservation efforts (Bourjea et al., 2015). In contrast, green turtles tagged in Vamizi migrated

10 through five EEZs to reach foraging grounds (Garnier et al., 2012) highlighting intra species

11 variation in behaviour of the same life stage. The final animal that showed residency within a single

12 EEZ, the sand tiger shark, is considered a coastal shark that does not typically move offshore

13 although it may range far distances along the coast (Dicken et al., 2007, Smale et al., 2012,

14 Bansemer \& Bennett 2011). For all the species in the present study that displayed some level of

15 transboundary movements (>2 EEZs), 78\% are considered threatened (as defined above). Although

16 it is reasonable to assume that these studies were undertaken given concern for the conservation

17 status of the study species, it is possible that many are threatened in part because of their long-

18 distance and transboundary movements that expose individuals to multiple fishing operations and

19 inconsistent management of critical habitats. While it is important to note that these studies are not

20 standardized with respect to tag type and attachment method, age, sex or statistical techniques to

21 process movement data, and that most studies have low sample sizes and a restricted number of

22 tracking days, these synthesized data still highlight the scale of transboundary movements in the

23 WIO.

24 Other biodiversity hotspots with high concentrations of regional boundaries, such as the

25 central Indo-Pacific and Caribbean Sea, likely reflect similar trends as observed here in the WIO

26 (see Harrison et al., 2018 for the Pacific Ocean). Telemetry data voids are often the result of limited 
1 funding available for marine conservation work in conjunction with limited capacity that hinders

2 both scientific research and enforcement. However, new research in the WIO continues to become

3 available (for example: Rohner et al., 2018 and Daly et al., 2018, published after the current meta-

4 analysis cut-off date), suggesting that effort is being made to increase scientific knowledge in the

5 region. Such studies are especially pertinent for the WIO to inform management as fisheries

6 exploitation in both coastal and offshore waters are estimated to be approaching maximum harvest

7 potential (FAO, 2016); an issue that is likely exacerbated by underreporting of artisanal catches

8 (Jacquet et al., 2010). Moving forward, data voids on species distributions in developing regions

9 of the world need to be addressed, with greater access to funding to promote development, self-

10 management and appropriate species conservation strategies.

\section{Acknowledgments}

13 We are extremely grateful to Peter Darnborough and the fishing crew of the Alleycat for assistance

14 with catching and tagging tiger sharks. We also wish to thank all the fishing operators in Watamu

15 for their support of this tagging program and Roy Beale for support in the field. This paper is a

16 contribution of ideasOTN, a synthesis committee from the Ocean Tracking Network (OTN).

17 Research in Kenya was covered under Research Permit No. NACOSTI/P/18/08032/21763 to

18 CORDIO East Africa, from the National Commission for Science, Technology and Innovation.

19 Fieldwork was funded through Selfridges Project Ocean. NEH was funded by NSERC Discovery

20 funds.

\section{Appendices \& Supplementary Material}

23 Appendix 1: Data sources for satellite tracked animals in the Western Indian Ocean.

\section{References}


1 Agnew, D. J., Pearce, J., Pramod, G., Peatman, T., Watson, R., Beddington, J. R., \& Pitcher, T. J.

2 (2009). Estimating the worldwide extent of illegal fishing. PloS one 4, e4570.

3 Allen, G. R. (2008). Conservation hotspots of biodiversity and endemism for Indo-Pacific coral

4 reef fishes. Aquat. Conserv. Mar. Freshwater Ecosyst 18(5), 541-56.

5 Ballard, G., Jongsomjit, D., Veloz, S. D., \& Ainley, D. G. (2012). Coexistence of mesopredatores

6 in an intact polar ocean ecosystem: the basis for defining a Ross Sea marine protected area. Biol.

7 Conserv. 152, 72-82.

8 Bansemer, C. S., \& Bennett, M. B. (2011). Sex-and maturity-based differences in movement and

9 migration patterns of grey nurse shark, Carcharias taurus, along the eastern coast of Australia.

10 Mar. Freshwater Res. 62(6), 596-606.

11 Bjørndal, T., Kaitala, V., Lindroos, M., \& Munro, G. R. (2000). The management of high seas

12 fisheries. Ann. Oper. Res. 94(1), 183-196.

13 Blaison, A., Jaquemet, S., Guyomard, D., Vangrevelynghe, G., Gazzo, T., Cliff, G., ... \& Soria,

14 M. (2015) Seasonal variability of bull and tiger shark presence on the west coast of Reunion

15 Island, western Indian Ocean. Afr. J. Mar. Sci. 37(2), 199-208.

16 Block, B. A., Jonsen, I. D., Jorgensen, S. J., Winship, A. J., Shaffer, S. A., Bograd, S. J., ... \&

17 Ganong, J. E. (2011). Tracking apex marine predator movements in a dynamic ocean. Nature

18 475(7354), 86-90.

19 Bonfil, R., Meÿer, M., Scholl, M.C., Johnson, R., O’Brien, S., Oosthuizen, H., ... \& Paterson, M.

20 (2005). Transoceanic migration, spatial dynamics, and population linkages of white sharks.

21 Science 310, 100-103.

22 Bourjea, J., Mortimer, J. A., Garnier, J., Okemwa, G., Godley, B. J., Hughes, G., ... \& Muths, D.

23 (2015). Population structure enhances perspectives on regional management of the western Indian

24 Ocean green turtle. Conserv. Genet. 16(5), 1069-1083.

25 Branch, G. M., Hauck, M., Siqwana-Ndulo, N., \& Dye, A. H. (2002). Defining fishers in the

26 South African context: subsistence, artisanal and small-scale commercial sectors. S. Afr. J. Mar.

27 Sci. 24(1), 475-487. 
1 Clark, C., Lea, J., \& Ormond, R. (2012). Comparative abundance of reef sharks in the Western

2 Indian Ocean. Proceedings of the $12^{\text {th }}$ international coral reef symposium, Cairns, Australia.

3 Cooke, S. J., Martins, E. G., Struthers, D. P., Gutowsky, L. F., Power, M., Doka, S. E., ... \&

4 Krueger, C. C. (2016). A moving target-incorporating knowledge of the spatial ecology of fish

5 into the assessment and management of freshwater fish populations. Environ Monit Assess,

6 188(4), 239.

7 Cooke, S. J., Hinch, S. G., Wikelski, M., Andrews, R. D., Kuchel, L. J., Wolcott, T. G., \& Butler,

8 P. J. (2004). Biotelemetry: a mechanistic approach to ecology. Trends Ecol. Evol. 19(6), 334-343.

9 Crossin, G. T., Heupel, M. R., Holbrook, C. M., Hussey, N. E., Lowerre-Barbieri, S. K., Nguyen, 10 V. M., ... \& Cooke, S. J. (2017). Acoustic telemetry and fisheries management. Ecol. Appl. 27(4), 11 1031-1049.

12 Dalla Rosa, L., Secchi, E. R., Maia, Y. G., Zerbini, A. N., \& Heide-Jørgensen, M. P. (2008).

13 Movements of satellite-monitored humpback whales on their feeding ground along the Antarctic

14 Peninsula. Polar Biol. 31(7), 771-81.

15 Dalleau, M., Benhamou, S., Sudre, J., Ciccione, S., \& Bourjea, J. (2014). The spatial ecology of 16 juvenile loggerhead turtles (Caretta caretta) in the Indian Ocean sheds light on the "lost years" 17 mystery. Mar. Biol. 161(8), 1835-1849.

18 Daly, R., Smale, M. J., Singh, S., Anders, D., Shivji, M., K. Daly, C. A., ... \& Clarke, C. R.

19 (2018). Refuges and risks: Evaluating the benefits of an expanded MPA network for mobile apex

20 predators. Divers. Distributions. doi: doi.org/10.1111/ddi.12758

21 Dicken, M. L., Booth, A. J., Smale, M. J., \& Cliff, G. (2007). Spatial and seasonal distribution 22 patterns of juvenile and adult raggedtooth sharks (Carcharias taurus) tagged off the east coast of 23 South Africa. Mar. Freshwater Res. 58(1), 127-134.

24 Dudley, S. F., \& Simpfendorfer, C. A. (2006). Population status of 14 shark species caught in the 25 protective gillnets off KwaZulu-Natal beaches, South Africa, 1978-2003. Mar. Freshwater Res. $2657(2), 225-40$.

27 Espinoza, M., Lédée, E. J., Simpfendorfer, C. A., Tobin, A. J., \& Heupel, M. R. (2015).

28 Contrasting movements and connectivity of reef-associated sharks using acoustic telemetry:

29 implications for management. Ecol. Appl. 25(8), 2101-2118. 
1 FAO (2016). The State of World Fisheries and Aquaculture 2016. Contributing to food security

2 and nutrition for all. Rome, 42-44pp.

3 FAO (2017). Major Fishing Areas; Indian Ocean, Western (Major Fishing Area 51). CWP Data

4 Collection. In: FAO Fisheries and Aquaculture Department, Rome. Accessed: 13 November

52017.

6 Fisk, A. T., Lydersen, C., \& Kovacs, K. M. (2012). Archival pop-off tag tracking of Greenland

7 sharks Somniosus microcephalus in the High Arctic waters of Svalbard, Norway. Mar. Ecol.

8 Prog. Ser. 468, 255-265.

9 Flanders Marine Institute (2016). Maritime Boundaries Geodatabase, version 1. Available online

10 at http://www.marineregions.org/. Consulted on 2017-11-09.

11 Folke, C. (2007). Social-ecological systems and adaptive governance of the commons. Ecol. Res. 12 22(1), 14-15.

13 Garnier, J., Hill, N., Guissamulo, A., Silva, I., Witt, M., \& Godley, B. (2012). Status and

14 community-based conservation of marine turtles in the northern Querimbas Islands

15 (Mozambique). Oryx, 46(3), 359-367.

16 Harris, L. R., Nel, R., Oosthuizen, H., Meÿer, M., Kotze, D., Anders, D., ... \& Bachoo, S. (2015).

17 efficient multi-species conservation and management are not always field-effective: The status

18 and future of Western Indian Ocean leatherbacks. Biol. Conserv. 191, 383-390.

19 Harrison, A. L., Costa, D. P., Winship, A. J., Benson, S. R., Bograd, S. J., Antolos, M., ... \&

20 Kohin, S. (2018). The political biogeography of migratory marine predators. Nat. Ecol. Evol. doi:

$21 \quad 10.1038 / \mathrm{s} 41559-018-0646-8$

22 Hays, G. C., Bradshaw, C. J. A., James, M. C., Lovell, P., \& Sims, D. W. (2007). Why do Argos

23 satellite tags deployed on marine animals stop transmitting? J. Exp. Mar. Biol. Ecol. 349(1), 52-

2460.

25 Hays, G. C., Ferreira, L. C., Sequeira, A. M., Meekan, M. G., Duarte, C. M., Bailey, H., ... \&

26 Eguíluz, V. M. (2016). Key questions in marine megafauna movement ecology. Trends Ecol.

27 Evol. 31(6), 463-475. 
1 Heithaus, M. R., Wirsing, A. J., Dill, L. M., \& Heithaus, L. I. (2007). Long-term movements of

2 tiger sharks satellite-tagged in Shark Bay, Western Australia. Mar. Biol. 151, 1455-1461.

3 Holmes, B. J., Pepperell, J. G., Griffiths, S. P., Jaine, F. R., Tibbetts, I. R., \& Bennett, M. B.

4 (2014). Tiger shark (Galeocerdo cuvier) movement patterns and habitat use determined by

5 satellite tagging in eastern Australian waters. Mar. Biol. 161(11), 2645-2658.

6 Howey-Jordan, L. A., Brooks, E. J., Abercrombie, D. L., Jordan, L. K., Brooks, A., Williams, S.,

$7 \quad$... \& Chapman, D. D. (2013). Complex movements, philopatry and expanded depth range of a

8 severely threatened pelagic shark, the oceanic whitetip (Carcharhinus longimanus) in the western

9 North Atlantic. PloS one 8(2), e56588.

10 Hussey, N. E., Hedges, K. J., Barkley, A. N., Treble, M. A., Peklova, I., Webber, D. M., ... \&

11 Fisk, A. T. (2017). Movements of a deep-water fish: establishing marine fisheries management

12 boundaries in coastal Arctic waters. Ecol. Appl. 27(3), 687-704.

13 Hussey, N. E., Kessel, S. T., Aarestrup, K., Cooke, S. J., Cowley, P. D., Fisk, A. T., ... \&

14 Flemming, J. E. M. (2015). Aquatic animal telemetry: a panoramic window into the underwater

15 world. Science 348(6240), 1255642.

16 Jacquet, J., Fox, H., Motta, H., Ngusaru, A., \& Zeller, D. (2010). Few data but many fish: Marine

17 small-scale fisheries catches for Mozambique and Tanzania. Afr. J. Mar. Sci. 32(2), 197-206.

18 Jorgensen, S. J., Reeb, C. A., Chapple, T. K., Anderson, S., Perle, C., Van Sommeran, S. R., ... \&

19 Block, B. A. (2009). Philopatry and migration of Pacific white sharks. Proc. R. Soc. London, Ser.

$20 \quad$ B rspb20091155.

21 Kaunda-Arara, B., \& Rose, G.A. (2004). Out-migration of tagged fish from marine reef national

22 parks to fisheries in coastal Kenya. Environ. Biol. Fishes 70(4), 363-372.

23 Lascelles, B., Notarbartolo Di Sciara, G., Agardy, T., Cuttelod, A., Eckert, S., Glowka, L., ... \&

24 Tetley, M. J. (2014). Migratory marine species: their status, threats and conservation management 25 needs. Aquat. Conserv. Mar. Freshwater Ecosyst. 24(S2), 111-127.

26 Marshall, N. (1998). The Kenyan shark fishery: a resource worth managing. Kenya Past and

27 Present 30(1), 18-24. 
1 Maxwell, S. M., Hazen, E. L., Lewison, R. L., Dunn, D. C., Bailey, H., Bograd, S. J., ... \&

2 Benson, S. (2015). Dynamic ocean management: Defining and conceptualizing real-time

3 management of the ocean. Mar. Policy 58, 42-50.

4 McMahon, C. R., \& Hays, G. C. (2006). Thermal niche, large-scale movements and implications

5 of climate change for a critically endangered marine vertebrate. Global Change Biol. 12, 1330-

61338.

7 McWhinnie, S. F. (2009). The tragedy of the commons in international fisheries: An empirical

8 examination. J. Environ. Econ. Manag. 57(3), 321-333.

9 Meyer, C. G., Papastamatiou, Y. P., \& Holland, K. N. (2010). A multiple instrument approach to

10 quantifying the movement patterns and habitat use of tiger (Galeocerdo cuvier) and Galapagos

11 sharks (Carcharhinus galapagensis) at French Frigate Shoals, Hawaii. Mar. Biol. 157(8), 1857-

121868.

13 Momanyi, A. (2015). Governance: Legal and Institutional Frameworks. In J. Paula (Eds.)

14 Regional State of the Coast Report Western Indian Ocean (pp. 445-457). Nairobi, Kenya: UNEP-

15 Nairobi Convention and WIOMSA.

16 Mora, C., Myers, R. A., Coll, M., Libralato, S., Pitcher, T. J., Sumaila, R. U., ... \& Worm, B.

17 (2009). Management effectiveness of the world's marine fisheries. PLoS Biol. 7(6), e1000131.

18 Morreale, S. J., Standora, E. A., Spotila, J.R., \& Paladino, F. V. (1996). Migration corridor for sea

19 turtles. Nature 384(6607), 319-320.

20 Navia, A. F., Cortés, E., \& Mejía-Falla, P. A. (2010). Topological analysis of the ecological

21 importance of elasmobranch fishes: A food web study on the Gulf of Tortugas, Colombia. Ecol.

22 Modell. 221(24), 2918-2926.

23 Nairobi Convention (2010). Final text of the Amended Nairobi convention for the protection,

24 management and development of the marine and coastal environment of the Western Indian

25 Ocean. Nairobi, Kenya 31 March 2010.

26 Obura, D. O., Church, J. E., \& Gabrié, C. (2012). Assessing marine heritage from an ecosystem

27 perspective: the western Indian Ocean. Paris, France: World Heritage Centre, United Nations

28 Education, Science and Cultural Organization (UNESCO). 
1 Okonkwo, T. (2017). Maritime boundaries delimitation and dispute resolution in Africa. Beijing

2 Law Rev. 8, 55-78.

3 Papastamatiou, Y. P., Meyer, C. G., Carvalho, F., Dale, J. J., Hutchinson, M. R., \& Holland, K.

4 N. (2013). Telemetry and random-walk models reveal complex patterns of partial migration in a

5 large marine predator. Ecology 94(11), 2595-606.

6 Pauly, D. (2015). The fisheries in the South-Western Indian Ocean, with emphasis on

7 reconstructed catches. Universidad de Alicante. Instituto Interdisciplinar para el Estudio del

8 Medio. doi: 10.14198/MDTRRA2015.ESP.02

9 Peklova, I., Hussey, N. E., Hedges, K. J., Treble, M. A., \& Fisk, A. T. (2012). Depth and

10 temperature preferences of the deepwater flatfish Greenland halibut Reinhardtius hippoglossoides

11 in an Arctic marine ecosystem. Mar. Ecol. Prog. Ser. 467, 193-205.

12 R Core Team (2017). R: A language and environment for statistical computing. R Foundation for

13 Statistical Computing, Vienna, Austria. URL https://www.R-project.org/.

14 Richmond, M. D. (2015). Threatened marine species. In J. Paula (Eds.) Regional State of the

15 Coast Report Western Indian Ocean (pp. 129-153). Nairobi, Kenya: UNEP-Nairobi Convention

16 and WIOMSA.

17 Robinson, L., \& Sauer, W. H. H. (2013). A first description of the artisanal shark fishery in

18 northern Madagascar: implications for management. Afr. J. Mar. Sci. 35(1), 9-15.

19 Rohner, C. A., Richardson, A. J., Jaine, F. R., Bennett, M. B., Weeks, S. J., Cliff, G., ... \& Pierce,

20 S. J. (2018). Satellite tagging highlights the importance of productive Mozambican coastal waters

21 to the ecology and conservation of whale sharks. PeerJ. 6, e4161.

22 Roquet, F., Williams, G., Hindell, M. A., Harcourt, R., McMahon, C., Guinet, C., ... \& Fedak, M.

23 (2014). A Southern Indian Ocean database of hydrographic profiles obtained with instrumented

24 elephant seals. Sci. Data 1.

25 Samoilys, M. A., Osuka, K., Maina, G. W., \& Obura, D. O. (2017). Artisanal fisheries on

26 Kenya's coral reefs: Decadal trends reveal management needs. Fish. Res. 186, 177-91.

27 Samoilys, M. A., Pabari, M., Andrew, T., Maina, G.W., Church, J., Momanyi, A., ... \& Mutta, D.

28 (2015). Resilience of Coastal Systems and their human partners; Ecological and social profile of 
1 coastal systems in Kenya, Mozambique and Tanzania. M. A. Fitzgerald (Eds). Nairobi, Kenya:

2 IUCN ESARO, WIOMSA, CORDIO and UNEP Nairobi Convention.

3 Smale, M. J. (2008). Pelagic shark fisheries in the Indian Ocean. In M. D. Camhi, E. K. Pikitch,

4 \& E. A. Babcock (Eds.), Sharks of the Open Ocean: Biology, Fisheries and Conservation (pp.

5 247-259). Oxford, UK: Blackwell Publishing Ltd.

6 Smale, M. J., Booth, A. J., Farquhar, M. R., Meÿer, M. R., \& Rochat, L. (2012). Migration and

7 habitat use of formerly captive and wild raggedtooth sharks (Carcharias taurus) on the southeast

8 coast of South Africa. Mar. Biol. Res. 8(2), 115-128.

9 Song, A.M., Scholtens, J., Stephen, J., Bavinck, M., \& Chuenpagdee, R. (2017). Transboundary

10 research in fisheries. Mar. Policy 76, 8-18.

11 Spalding, M. D., Fox, H. E., Allen, G. R., Davidson, N., Ferdaña, Z. A., Finlayson, M. A. X., ,..

$12 \&$ Martin, K. D. (2007). Marine ecoregions of the world: a bioregionalization of coastal and shelf

13 areas. BioScience 57(7), 573-583.

14 Sumaila, U.R., Samoilys, M., Allison, E., Cinner, J., DeYoung, C. \& Kavanagh, C. (2014).

15 Economic Impacts of Ocean Acidification on Fisheries and Aquaculture in the Western Indian

16 Ocean: Current Knowledge and Recommendations. Indian Ocean and Red Sea (FAO 51, 57),

17 IAEA Report.

18 Tittensor, D. P., Mora, C., Jetz, W., Lotze, H. K., Ricard, D., Berghe, E. V., \& Worm, B. (2010).

19 Global patterns and predictors of marine biodiversity across taxa. Nature, 466(7310), 1098.

20 UNEP/Nairobi Convention Secretariat and WIOMSA (2009). Transboundary diagnostic analysis

21 of land-based sources and activities affecting the Western Indian Ocean coastal and marine

22 environment. UNEP. Nairobi, Kenya

23 Wafar, M., Venkataraman, K., Ingole, B., Khan, S. A., \& LokaBharathi, P. (2011). State of

24 knowledge of coastal and marine biodiversity of Indian Ocean countries. PLoS One 6(1), e14613.

25 Wildlife Conservation Society (WCS) in press. Sharks and rays of the western Indian Ocean -

26 Biodiversity, fisheries and trade, management, and conservation. Report for the Nairobi

27 Convention. 
1 Werry, J. M., Planes, S., Berumen, M. L., Lee, K. A., Braun, C. D., \& Clua, E. (2014). Reef-

2 fidelity and migration of tiger sharks, Galeocerdo cuvier, across the Coral Sea. PLoS One 9(1),

3 e83249.

4 West, C. D., Dytham, C., Righton, D., \& Pitchford, J. W. (2009). Preventing overexploitation of 5 migratory fish stocks: the efficacy of marine protected areas in a stochastic environment. ICES J.

6 Mar. Sci. 66(9), 1919-1930.

7 White, T. D., Carlisle, A. B., Kroodsma, D. A., Block, B. A., Casagrandi, R., De Leo, G. A., ... \&

8 McCauley, D. J. (2017). Assessing the effectiveness of a large marine protected area for reef

9 shark conservation. Biol. Conserv. 207, 64-71.

10 White, C., \& Costello, C. (2014). Close the high seas to fishing? PLoS Biol 12(3), e1001826.

11 Worm, B., \& Branch, T. A. (2012). The future of fish. Trends Ecol. Evol. 27(11), 594-599. 
Table 1- Satellite telemetry studies undertaken within the western Indian Ocean. Full references can be found in Appendix 1. The first column

2 includes the species common name with the scientific name in brackets and the IUCN red list status in bold below. EEZ \# stands for the number of

3 exclusive economic zones crossed by the study species, where studies that were not applicable for this analysis are indicated by ' $\mathrm{n} / \mathrm{a}$ ' or further

4 justification is given. Sample size is the number of animals equipped with satellite tags, with the minimum and maximum range of days tracked for

5 those animals in brackets. When the day range was not available, the average number of days \pm standard deviation is reported.

\begin{tabular}{|c|c|c|c|c|c|c|}
\hline $\begin{array}{c}\text { Species \& IUCN } \\
\text { red list status }\end{array}$ & Authors & Year & Country & Capture/release location & EEZ \# & $\begin{array}{l}\text { Sample size (day } \\
\text { range or average) }\end{array}$ \\
\hline \multirow{4}{*}{$\begin{array}{l}\text { Loggerhead turtle } \\
\text { (Caretta caretta) } \\
\text { Vulnerable }\end{array}$} & Hays et al. & 2003 & $\mathrm{n} / \mathrm{a}$ & Indian Ocean & $\mathrm{n} / \mathrm{a}$ & \\
\hline & Luschi et al. & 2006 & South Africa & Maputaland Marine Reserve & review & \\
\hline & Mencacci et al. & 2010 & South Africa & Maputaland Marine Reserve & *omitted & \\
\hline & Dalleau et al. & 2014 & France & Reunion Island & 13 & $18(20-401)$ \\
\hline \multirow{5}{*}{$\begin{array}{l}\text { Leatherback turtle } \\
\text { (Dermochelys } \\
\text { coriacea) } \\
\text { Vulnerable }\end{array}$} & Hughes et al. & 1998 & South Africa & Maputaland Marine Reserve & $4^{\mathrm{a}}$ & $1(114)^{\mathrm{a}}$ \\
\hline & Hays et al. & 2003 & $\mathrm{n} / \mathrm{a}$ & Indian Ocean & $\mathrm{n} / \mathrm{a}$ & \\
\hline & Luschi et al. (b) & 2003 & South Africa & Maputaland Marine Reserve & $4^{\mathrm{a}}$ & $3(124-223)^{\mathrm{a}}$ \\
\hline & Sale et al. & 2006 & South Africa & Maputaland Marine Reserve & $4^{\mathrm{a}}$ & $4(16-168)^{a}$ \\
\hline & Luschi et al. & 2006 & South Africa & Maputaland Marine Reserve & review & \\
\hline
\end{tabular}




\begin{tabular}{|c|c|c|c|c|c|c|}
\hline $\begin{array}{l}\text { Green turtle } \\
\text { (Chelonia mydas) }\end{array}$ & Garnier et al. & 2012 & Mozambique & Vamizi & 5 & $4(127-231)$ \\
\hline Endangered & Bourjea et al. & 2015 & Seychelles & Amirantes & 1 & $4\left(39-175^{\dagger}\right)$ \\
\hline $\begin{array}{l}\text { White shark } \\
\text { (Carcharodon } \\
\text { carcharias) } \\
\text { Vulnerable } \\
\end{array}$ & Bonfil et al. & 2005 & South Africa & Gansbaai & 4 & $24(31-371)$ \\
\hline \multirow{4}{*}{$\begin{array}{l}\text { Whale shark } \\
\text { (Rhincodon typus) } \\
\text { Endangered }\end{array}$} & Gifford et al. & 2007 & South Africa & Cape Vidal & 2 & $5(2-132)$ \\
\hline & Rowat \& Gore & 2007 & Seychelles & Mahe & 3 & $9(7-123)$ \\
\hline & Brunnschweiler et al. & 2009 & Mozambique & Tofo & $2^{\mathrm{b}}$ & $1(87)^{b}$ \\
\hline & Brunnschweiler et al. & 2011 & Mozambique & Tofo & $2^{\mathrm{b}}$ & $1(87)^{b}$ \\
\hline $\begin{array}{l}\text { Bull shark } \\
\text { (Carcharhinus } \\
\text { leucas) } \\
\text { Near threatened }\end{array}$ & Lea et al. & 2015 & Seychelles & Amirantes & 4 & $1(151)$ \\
\hline $\begin{array}{l}\text { Sand tiger shark } \\
\text { (Carcharias taurus) } \\
\text { Vulnerable }\end{array}$ & Smale et al. & 2012 & South Africa & Struis Bay & 1 & $5(43-126)$ \\
\hline $\begin{array}{l}\text { Ocean sunfish } \\
(\text { Mola mola }) \\
\text { Vulnerable }\end{array}$ & Hays et al. & 2009 & South Africa & near Cape Bay & 2 & $4(64-208)$ \\
\hline $\begin{array}{l}\text { Elephant seal } \\
\text { (Mirounga leonina) } \\
\text { Least Concern }\end{array}$ & Roquet et al. & 2014 & South Africa & $\begin{array}{c}\text { Kerguelen Isl., Davis Station, } \\
\text { Casey Station }\end{array}$ & $\mathrm{n} / \mathrm{a}$ & 207 (n/a) \\
\hline $\begin{array}{l}\text { Southern right } \\
\text { whale (Eubalaena }\end{array}$ & Mate \& Best & 2008 & South Africa & $\begin{array}{c}\text { Saldanha Bay and St. Sebastien } \\
\text { Bay }\end{array}$ & $4^{c}$ & $21(1-161)^{\mathrm{c}}$ \\
\hline $\begin{array}{l}\text { australis) } \\
\text { Least Concern }\end{array}$ & Mate et al. & 2011 & South Africa & St. Helena Bay & $4^{\mathrm{c}}$ & $21(1-161)^{\mathrm{c}}$ \\
\hline $\begin{array}{l}\text { Humpback whale } \\
\text { (Megaptera }\end{array}$ & Fossette et al. & 2014 & Comoros & $\begin{array}{l}\text { Moheli Island and Mayotte } \\
\text { Island }\end{array}$ & 6 & $11(8-49)$ \\
\hline novaeangliae) & Cerchio et al. & 2016 & Madagascar & Ile Saite Marie and Anakao & $7^{\mathrm{d}}$ & $23(2-58)^{d}$ \\
\hline Least Concern & Trudelle et $a l$. & 2016 & Madagascar & Ile Saite Marie and Anakao & $7^{\mathrm{d}}$ & $25(2-58)^{d}$ \\
\hline
\end{tabular}


a,b,c,d Tracks that have been combined as the data is reused in multiple studies, sample sizes and day ranges reflect combinations of animals that were tracked in multiple studies and novel ones.

*Omitted as these turtles were relocated and released in a novel location

4 'Day ranges that were not explicitly reported, but calculated from available data. 
1 Table 2- Information on tiger sharks equipped with satellite tags off the coast of Kenya. TL =

2 total length, $\mathrm{F}=$ female, $\mathrm{M}=$ male. Number of geolocations is the total number of locations

3 provided by the satellite tags (location quality $1-3, \mathrm{~A}$ and $\mathrm{B}$ ).

\begin{tabular}{lccccccc}
$\begin{array}{c}\text { Shark } \\
\text { number }\end{array}$ & $\begin{array}{c}\text { Size } \\
\text { (TL) }\end{array}$ & Sex & $\begin{array}{c}\text { Tag } \\
\text { model }\end{array}$ & $\begin{array}{c}\text { Date } \\
\text { tagged }\end{array}$ & $\begin{array}{c}\text { Number of } \\
\text { geolocations }\end{array}$ & $\begin{array}{c}\text { Days } \\
\text { tracked }\end{array}$ & $\begin{array}{c}\text { Distance } \\
\text { travelled }\end{array}$ \\
\hline TS01 & 330 & F & 257A & $21-11-2014$ & 45 & 44 & $272 \mathrm{~km}$ \\
\hline TS02 & 380 & F & 257A & $03-12-2014$ & 96 & 35 & $536 \mathrm{~km}$ \\
\hline TS03 & 280 & F & 258A & $02-12-2014$ & 162 & 66 & $2926 \mathrm{~km}$ \\
\hline TS04 & 280 & F & 258A & $02-12-2014$ & 556 & 235 & $4779 \mathrm{~km}$ \\
\hline TS05 & 324 & F & 258A & $04-12-2014$ & 0 & 0 & $\mathrm{n} / \mathrm{a}$ \\
\hline
\end{tabular}

4 
1 Figure 1-Cumulative number of studies on satellite tracked marine animals over time, separated

2 by the global total encompassing all world oceans (Hussey et al., 2015), and those which only

3 took place within the Western Indian Ocean.

4 Figure 2- Satellite tracks of all animals studied up to December 2016 within the Western Indian

5 Ocean, extracted from published papers (see Table 1 for references). Coloured areas mark unique

6 country exclusive economic zones. Tracks are colour coded based on taxon. In the case of pop-up

7 archival satellite telemetry studies where only the tagging and pop-up location of the tag are

8 provided, locations were marked by a star.

9 Figure 3- Satellite tracks of individual tiger sharks (Galeocerdo cuvier) tagged off the coast of

10 Kenya in the Western Indian Ocean. Exclusive economic zone boundaries are marked with black

11 lines; FSL stands for French Southern Lands.

12 Figure 4- Occurrence of tiger sharks (Galeocerdo cuvier) in the exclusive economic zones (EEZ)

13 of countries within the Western Indian Ocean, presented as a percentage of the number of days

14 spent in each EEZ out of the total number of days that animal was tracked (total days indicated by

15 'n' above each bar). Note: FSL stands for French Southern Lands.

16 Figure 5- Number of EEZs crossed by all species tracked with satellite tags in the Western Indian

17 Ocean up until December 2016. Each colour refers to a unique reference track for that species,

18 which may encompass one or more references depending on if the track is unique to a study or

19 used in multiple studies. 
Figure 1

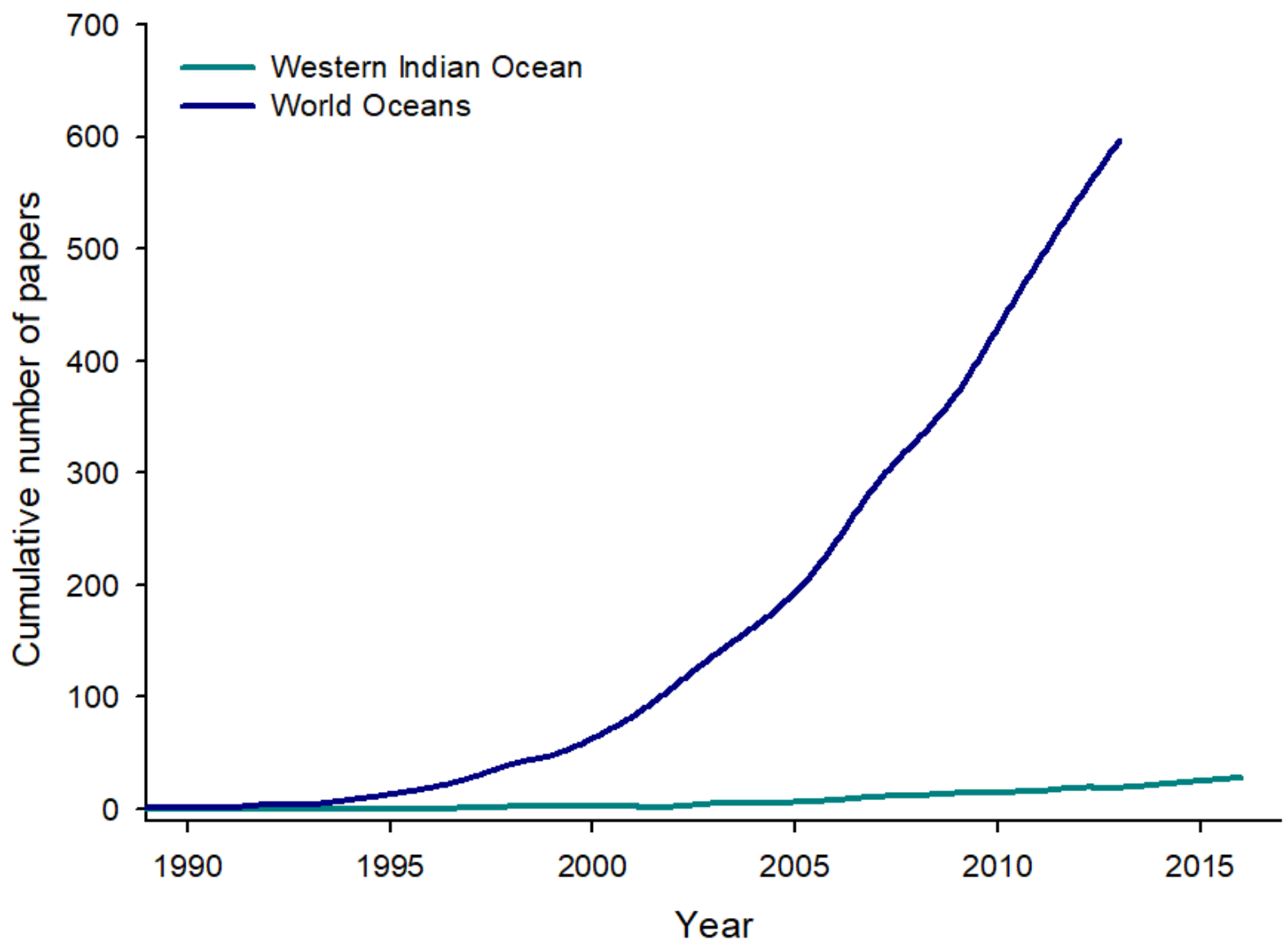

2 
Figure 2

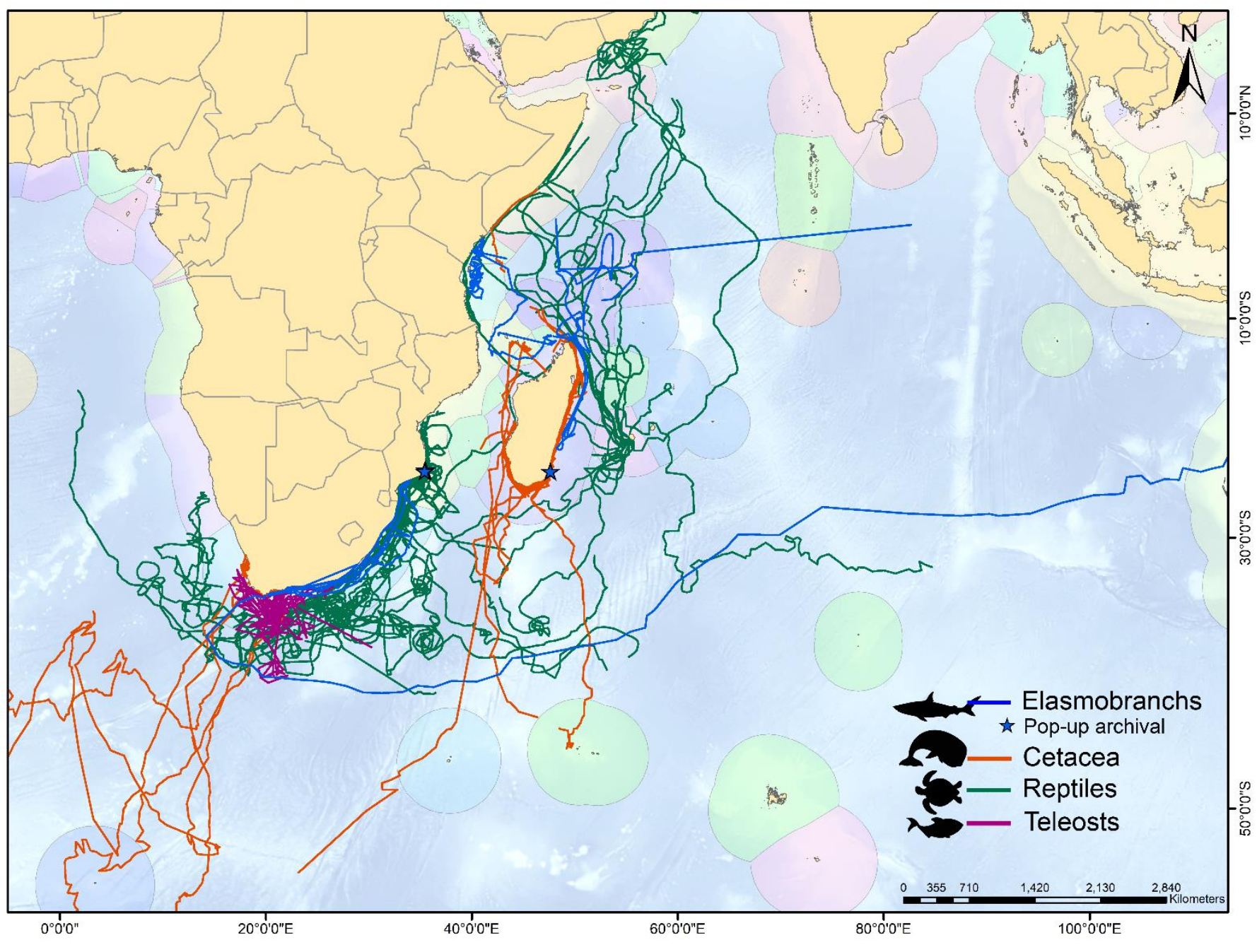


Figure 3

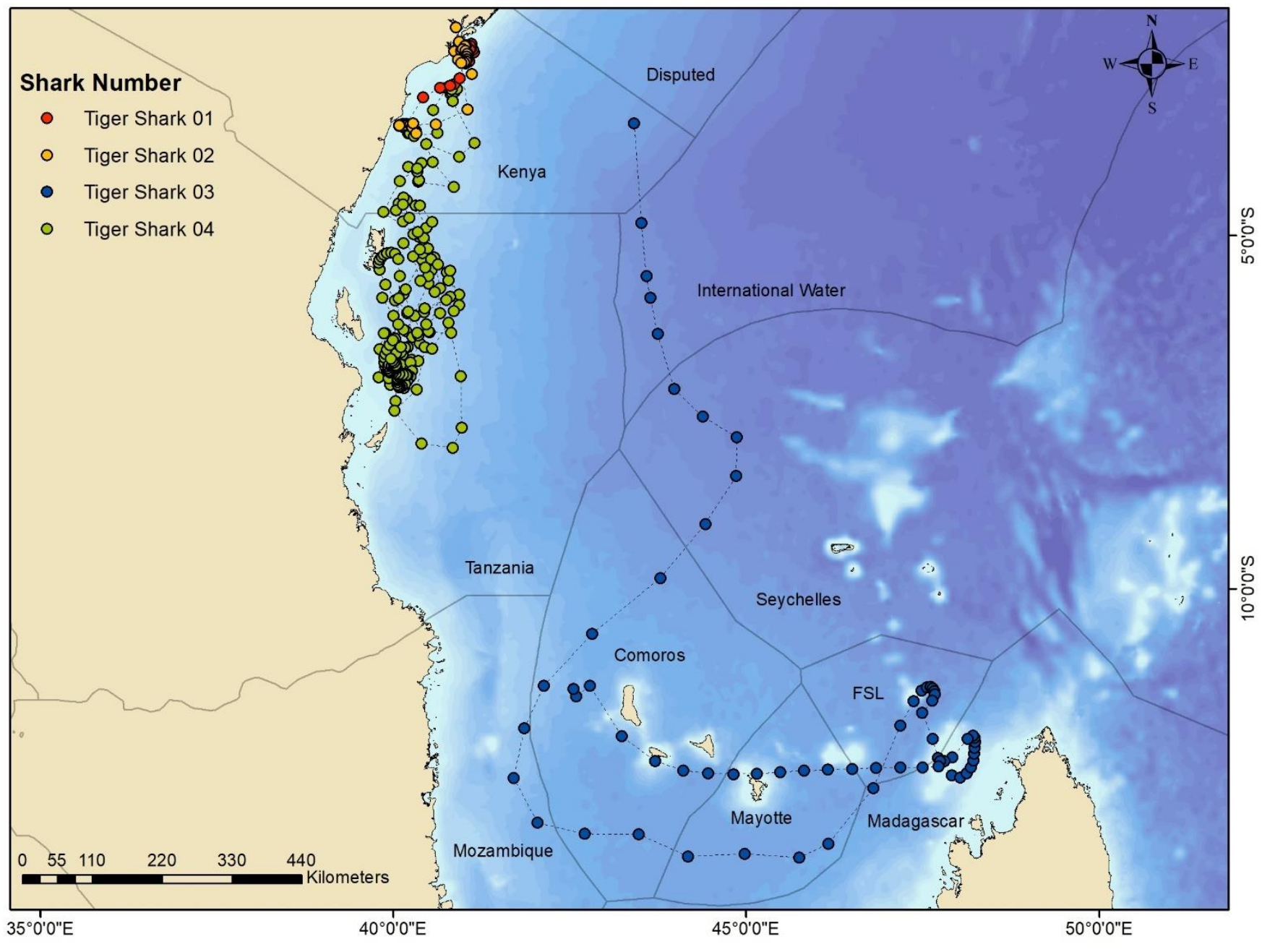


$1 \quad$ Figure 4

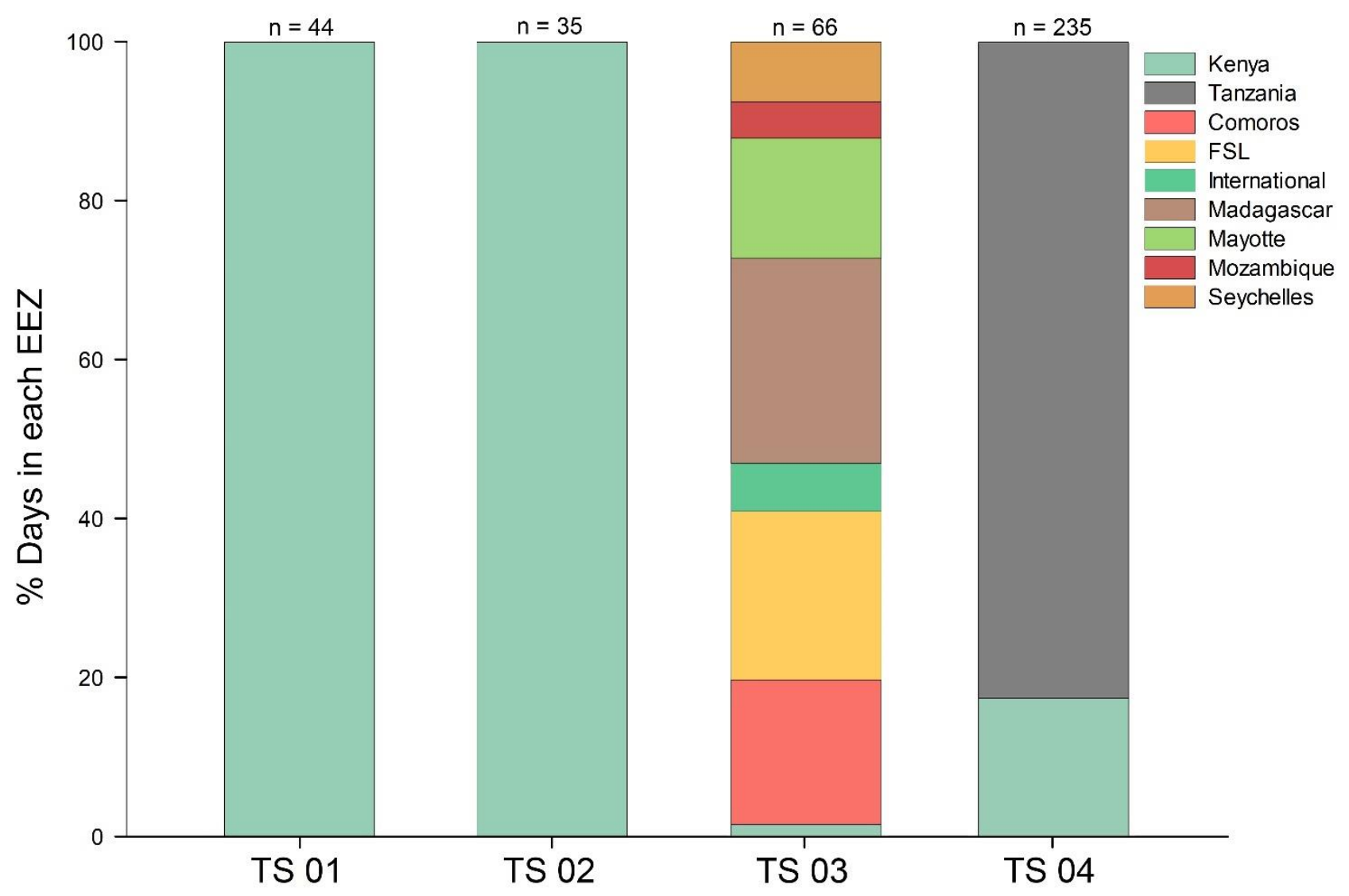


Figure 5

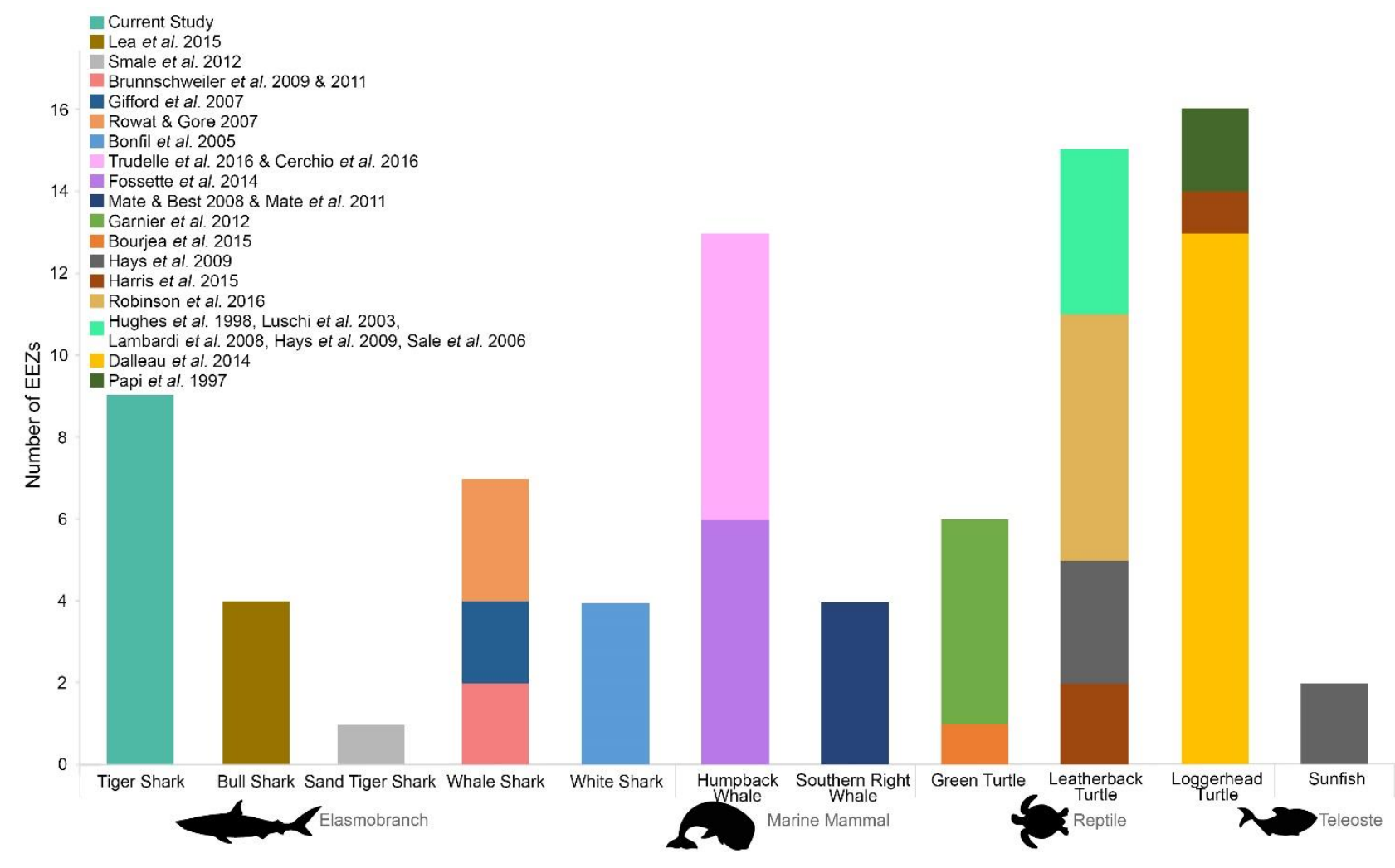

